\title{
Humanistic - Behavioral - Cultural Competitive Advantage of the Enterprises - Concept Models
}

\author{
„Human being requires knowing. Human being as the basis of an organization. \\ Knowing an organization is an appropriate man, whom you can lean on". 1
}

Michał Adam Leśniewski

\author{
Michał Adam Leśniewski
}

Dr, Adjunct Professor, Department of Management, University of Jan Kochanowski in Kielce, Poland

\begin{abstract}
The functioning of any organization, including business, is based on people thanks to whom you can shape the competitiveness and competitive advantage. Managers and subordinates are to work together for the good of the entire organization. Employees should be positive for other people and positively engaged in the performance of their duties. Positivity of a person derives from positive psychology contributing to the positive development of the knowledge manager and a positive subordinate. The aim of the study is to show the humanistic - behavioral - cultural competitive advantage of the enterprises seen through the prism of a positive knowledge manager and a positive subordinate. In the following study, two research hypotheses were taken: Research hypothesis 1: Humanism, Behaviourism, and Organizational culture are the attributes of a person enabling the achievement of competitive advantage; Research hypothesis 2: Knowledge manager and subordinate let positivity guide shaping the competitive advantage of enterprises. Presented hypotheses are developed using the method of interpretation of the available literature. The findings may be useful for science theoreticians and practitioners of economic management, including managers at all levels of management and executive employees (subordinates). In this study, conceptual models were presented.
\end{abstract}

Keywords: humanistic competitive advantage, behavioral competitive advantage, cultural competitive advantage, concept models, knowledge manager.

JEL Classification: D21, D23, O15.

Cite as: Leśniewski, M.A. (2019). Humanistic - Behavioral - Cultural Competitive Advantage of the Enterprises - Concept Models. Business Ethics and Leadership, 3(1), 34-43. http://doi.org/10.21272/bel.3(1).34-43.2019.

(C) The Author, 2019. This article is published with open access at Sumy State University.

\section{Introduction}

Shaping the development of the organization (company) is the ability to meet the different requirements generated by the environment. With a workforce, including managers and subordinates, one can achieve much, guided by the quality of employees who, through their commitment and contribution of certain intellectual contribution will contribute to the development of the organization. One of the ideas, concepts shaping the competitiveness and competitive advantage are: positive knowledge manager, subordinate, and the positive attributes of the human form: humanism, behaviourism and personal culture, including organizational culture. These components fully fit in soft management achievements. Positive psychology has also contributed to a positive knowledge manager and positive subordinates who work together to create benefits for themselves and the whole organization. Examination of the manager and the subordinate in a positive context shows that there must be a healthy relationship between the manager and the subordinate, they must have well-being, which is a fundamental issue of positive psychology. The manager is also a person of substance or having certain knowledge - knowledge manager. Subordinate also must have the knowledge, but from the point of view of the management, decision-making is the job of the manager, not subordinate.

The aim of the study is to show the humanistic - behavioral - cultural competitive advantage of the enterprises seen through the prism of a positive knowledge manager and a positive subordinate. In the following study, two research hypotheses were taken: Research hypothesis 1: Humanism, Behaviourism, and Organizational culture are the attributes of a person enabling the achievement of competitive

${ }^{1}$ (Leśniewski, 2018a, s. 123). 
advantage, Research hypothesis 2: Knowledge manager and subordinate let positivity guide shaping the competitive advantage of enterprises. Presented hypotheses are developed using the method of interpretation of the available literature, which included: logical assumption (logical thinking) and perception; it allows to combine different aspects into one compact unit and giving the image of the analyzed reality surrounding the author. This method makes it possible to present the viewpoint of the author's development. In this method, inter alia, theoretical experience, practical experience and theoretical and practical experience (combining theory and practice) are used. The logical reasoning - from the perspective of the author of the study - this method can be called the queen of methods (Leśniewski, 2017: 78). In this study, conceptual models were presented.

\section{Positive knowledge manager in business development}

Knowledge (Leśniewski, 2015: 171-187) is one of the resources that contribute to the development of a person as a skilled worker and accompanies a single employee, staff groups and the entire organization in every aspect of social and economic life. Knowledge is inseparable from the man or the man as the creator, the creator and the recipient, an impersonator of knowledge (human - creator of knowledge, man - knowledge impersonator). One of the features that characterizes the staff is that each of them has different levels of knowledge, specialization and the possibility of its transferring. Managers and subordinates must act in concert to generate a style of communication that contribute to mutual understanding. You must have this level of expertise, which, together with conceptual thinking, enables executives to create a mechanism to generate new knowledge that will contribute to the creation of new resources giving future development. Any organization (company) is moving in the direction of being unique and not reproducible in a competitive market (have one's DNA). Knowledge is not only a manifestation of the substance of a manager and a subordinate but also partial anticipation, sensing, feeling upcoming changes (manager's intuition, subordinate's intuition).

Considering the knowledge in the context of the manager from the point of view of the process management (McKeen, Staples, 2003: 21-41) one can attempt to define the concept of positive knowledge manager. The role of positive knowledge manager is to use his knowledge, which will lead the organization to achieve the benefits of the market that is what the market will give positively to the organization. The welfare of an organization is achieved by positive knowledge manager.

Positive knowledge manager (Asllani, Luthans, 2003: 53-66) would be responsible, inter alia, for the transfer of knowledge in an enterprise on the line: enterprise - business incubator (technological parks, academic incubators etc.). The manager would contribute to the closeting of Business to Science or Science to Business. Both science and business have much to offer each other. Positive knowledge manager is not just a person working in the company but also the person working at universities or other research organizations (universities manager, manager research institute etc.). The manager can fully manage not only an economic entity but also the institution of higher education. Positive manager of knowledge can be defined as a person who is capable of substantive usage in different ways of the knowledge possessed by himself, he knows how to think conceptually and has to think of the implementation efforts. The manager knows how to develop the concept of the transfer of knowledge between different organizations. He has a positive attitude towards people and changes in the environment. In the knowledge economy, it is reasonable to consider such a concept of manager in the long-term development of the organization, in both companies and universities and other types of organizations.

Positive knowledge manager (Romańczuk, 2003: 141) is to be characterized by a positive attitude to the people, the pursuit of happiness and the manager has to have, as far as possible, attributes derived from positive psychology. Changes should be seen through the prism of positive thinking. He must be consistent in his actions. He has the ability to see ahead to solve each problem, he has to act proactively, to take various initiatives. The behavior of positive knowledge manager has to come from the wider welfare and positive perception of the changes. His behaviourism is to be directed by way of positive psychology and positive potential of the organization. People with a positive attitude live better, easier and happier.

Below is a conceptual model of positive knowledge manager. 


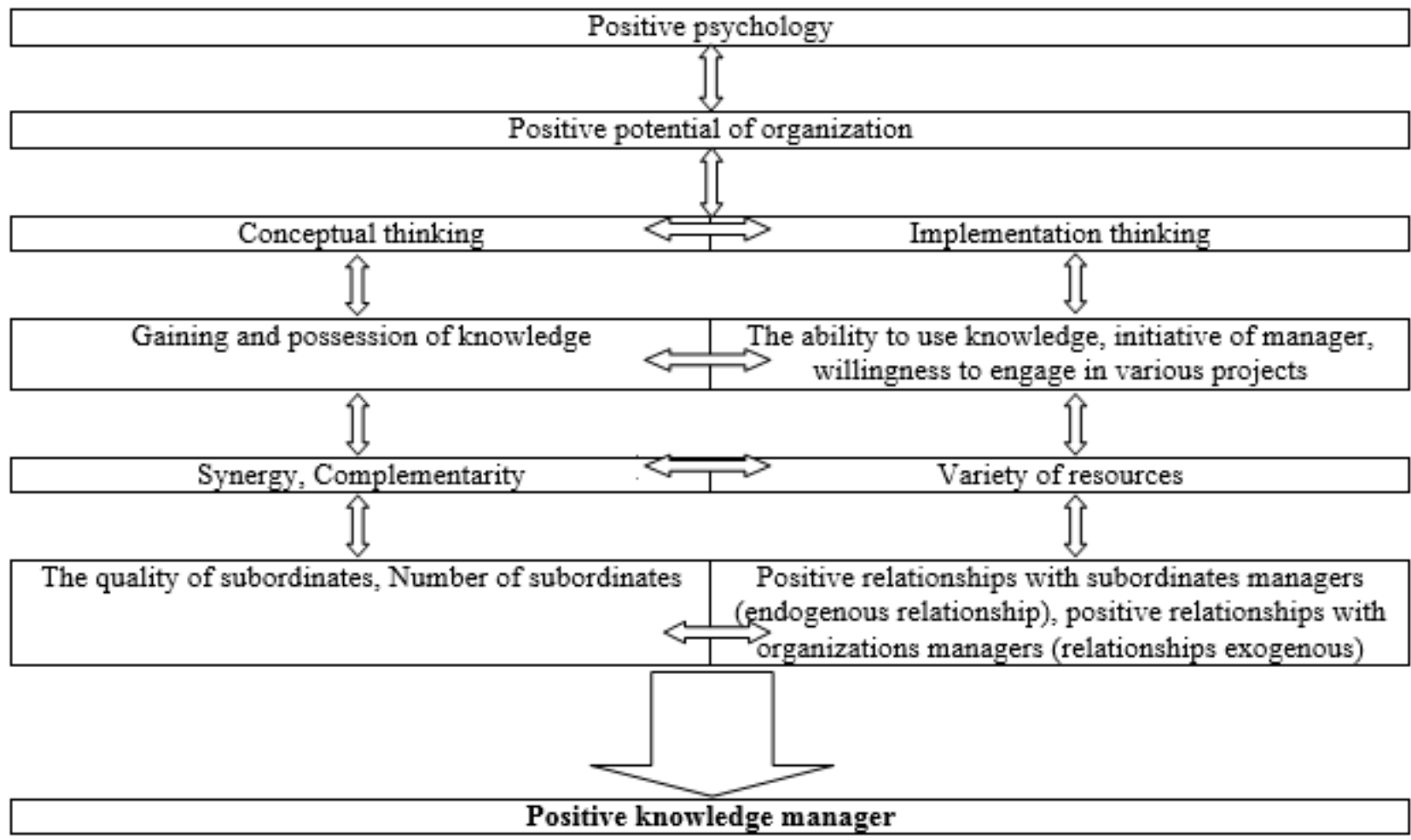

Figure 1. Positive knowledge manager - conceptual model

Source: Own authoring based on: (Leśniewski, 2018: 91)

Positive knowledge manager is a person who wants to and is able to contribute to the effective and efficient development of employees and the entire organization. To develop the concept of a positive manager of knowledge shown in the figure above, you should first read the positive psychology. This is due to the fact that every human being strives for happiness that is to be positive about the world. Answers to the question of what to do to be a happy person are given by positive psychology, which highlights the strengths of individuals, focuses on how to induce positive emotions, how to shape the advantages and virtues of a person as improvement to positive institutions that favor the development of the individual - all in order to strengthen human happiness and make it everlasting. The aim of positive psychology is to improve the welfare of every human being, regardless of his age and health (Gulla, Tucholska, 2007: 134).

What is good, positive trends began to penetrate into different organizations. These units began to shape good at home, which contributed to the emergence of the concept of Positive Potential of Organization (PPO) (Zbierowski, 2012; Glińska-Neweś, 2010: 37-52; Haffer, 2010: 159-213). The importance of positive trends in the development of the organization's success stems from the fact that they promote the development of employees' potential, enrich their individual opportunities, broaden the horizons of knowledge, create a feeling of confidence and also allow you to create innovative solutions and achieve superior results (individually and collectively). Creative processes in the organization are conditioned by workers experiencing positive emotions that stimulate and motivate them to seek perfection, conducive to the pursuit of above-average results and allow broadening the horizons of creative thinking and experimentation. Improving knowledge is a positive attitude to the changes. The positive potential shapes the behavior of proactive staff. Achieving superior results of work contributes to achieving personal goals and aspirations of employees while becoming a catalyst for the development of the whole organization (Roberts, 2007: 29-45). As a result, the organization creates the so-called "Positive spiral": positive emotions favor the sense of positive energy by workers who contribute to the commitment to improve the efficiency of the entire organization, and this, in turn, increases the feeling of positive emotions by employees (Fredrickson, 2003: 163-173).

Thinking is an inherent attribute of a person. In this regard, the positive knowledge manager in order to be able to pursue his mission to subordinates and organizations must develop conceptual thinking and implementation thinking. It is very important to have an idea, a concept and the ability to implement the concept of the organization. It can be argued that conceptual thinking and implementation thinking are of complementary, mutually supportive nature.

Positive knowledge manager (Perechuda, 2005: 9-15) while capturing and exploiting knowledge derived from the direction of positive psychology and positive potential of the organization has a strong base of knowledge of being a manager stimulated by positives of positive knowledge manager. Positive knowledge manager is a 
management team with a high level of not only the content but also a high level of responsibility for changes in the business entity. This manager will be happy to take the initiative and willingly engages in a variety of undertakings. This model is to be fully adapted to the conditions of operation of each company. Knowledge, in order to bear fruit for the organization, must be added to the component in the form of the ability to use knowledge (Krogh, 1998: 133-153). Knowledge and skill is a typical example of complementarily and synergy. The organization manager must also pursue the process of synergy and complementarily and generate a variety of resources that will enrich the value of the organization. The resource diversity can be seen - to use a metaphor - as the so-called "Bottomless pit", where you can meet with such resources, which currently does not have and after some time these resources appear (conceptual thinking). Another positive feature of the model of the knowledge manager is the quality and quantity of subordinates. Subordinates as employees of the organization are presented in two categories: quality and quantity. Author of the model of positive knowledge manager is a proponent of a qualitative look at subordinates, starting from the premise that not quantity but quality is the value of the employee - subordinates. Given that the other side of the workers in the organization is the amount, one should generate skillfully from the number of workers the quality of employees (keep in mind that not always you can bring quality from the amount). Employee quality will give more of himself than a quantitative employee. The quality and quantity of employees shape relationships on the line: manager subordinate. You can, in the context of the quality and quantity of employees, create a qualitative and quantitative picture of the man (employee). Human functioning in and outside the organization is based, inter alia, on relationships, which in most cases should be a positive relationship. The relationship is all about creating a positive attitude towards a person. The manager has to understand the subordinate and the subordinate has to understand the manager. Both endogenous and exogenous relations should be based on mutual understanding, respect for the welfare of each party. All the above factors are a model of the concept of positive knowledge manager.

\section{Humanism, Behaviourism and Organizational culture as the components of the competitive advantage of the enterprises in the prism of soft management}

A person is the primary resource of organizations, including enterprises (Leśniewski, 2014: 57-68) beginning all the processes in the organization and beyond, contributing to the development and success of the organization (the creator of man, man wizard). Keep in mind that a person is also a resource that could contribute to failure and ultimate collapse of the organization (man destructor). Therefore, it is very important to have quality employees who are in the category - the man-creator. By entering the building, shaping the competitiveness of enterprises should have the quality employees (man creator), who are acting as the manager and the subordinate will engage to make it possible to generate competitiveness or competitive advantage. Concept faithfully typing in a relationship of a person with competitiveness is Competitiveness person (Leśniewski, 2018a: 123-135). The concept of the Competitiveness person leads the organization (enterprise) on the road of dynamics of competitiveness factors, and therefore of achieving competitive advantage.

\section{Humanism}

The main representatives of the School of humanistic (in other words: the concept of humanistic, humanistic approach, humanistic trend) are A. Maslow and C. Rogers. A. Maslow led a reflection on the healthy and creative individuals. He postulated that science moved away from the analysis of a sick person, dysfunctional, and focused on what is good and what optimistic, what builds the capacity of units. Leading research of selffulfilling people to create a positive psychological portrait of the individual, having confidence in yourself and others (Hall, Lindzey, 2001), he postulated the need for a holistic and dynamic approach to the units. Only such approach provides an in-depth understanding and permanent removal of possible problems (Maslow, 2006). The focus on the individual (worker, student, patient) can prevent an unfair assignment of the label and stigma to the role of fierce, daring, unpredictable people, which determines to a large extent their further functioning. His proposal for a business A. Maslow formulated under the name eupsychic management, involving the humanitarian approach to people (in the center there is a person with his individual needs, a person and his perspective). In the longer term, such a philosophy of action can also bring financial benefits (Cox, 2006). The latter of "the fathers" of humanistic approach, C. R. Rogers, is the creator of the concept of non-directive therapy, client-centered. It is based on the empathic bond between the customer and a facilitating person. Its principles are widely used in counseling, conducting meeting groups and conflict resolution group (Hall, Lindzey, 2001). This therapy is based on a genuine relationship between a student and a teacher and is widely used in the training of medical personnel, vocational guidance, training of personnel management, training animators and local communities in different cultures (Rogers, 1991). With the humanistic concept in business, you could look differently at the employee, seeing his individuality, creativity and the desire to develop. The keynote of humanistic concept is that a man is a unit integrated into the unique environment in 
ISSN (online) - 2520-6311; ISSN (print) - 2520-6761

which he lives; human development is conditioned by factors stuck in himself and beyond; a man strives for self-realization; a man is good by his nature of existence and positively disposed toward the world around him; human behavior is conditioned by the present, by what he represents "here" and "now"; a man who lives in the past does not reach full development. The humanistic school puts the human in the spotlight as a unit which has needs and perspectives in the development of oneself and others (eg. the organization). You can say at this point that humanistic school has created humanistic management. Soft management is also originated on this ground.

\section{Behaviourism}

A person is not only necessities, development or perspective but also behavior (behaviourism) resulting from different conditionings. Behaviorist trend appeared officially in 1913 thanks to behaviorist manifesto delivered by JB Watson's, however, it had its precursors in the form of i.e. Pavlov I. and E. Thorndike (Stachowski, 2000). J. Watson concentrated in his analysis on the factors that improve human functioning, and for the purpose of science as experimental psychology, he took control of the behavior and the ability to predict. The concept of J. Watson, extremely reductionist, is called the psychology of stimulus and response. According to it, the body is affected by a lot of various stimuli, stimulating it and causing reactions in the form of physiological arousal, motor, emotional, and even mental (Matusewicz, 2006). J. Watson claimed that influence of the environment is so powerful, that regardless of the internal factors it can shape any expert even if his skill would be based on the talent (eg. plastic, music) (Trojan, 2014). Another representative of the behavioral school is Burrhus F. Skinner, who drew attention to the rewards and punishments that shape individual behavior and stressed that deprivation of stimuli leads to pathology in the behaviors of the individual (Ziółkowska, 2008). Such a state can be experienced by eg. a person mobbed, who among others things, is not assigned tasks, has limited communications, is isolated from the same stimuli characteristic of the work environment. On regularities related to the use of reinforcements you can lean also while creating incentive systems, and meta-analysis of a number of American data research revealed dominance of the impact of financial incentives (especially those dependent on the results) on work performance, reduction of absenteeism and staff turnover over the non-financial factors (Tyszka, Zaleśkiewicz, 2004). This proves that the employee behaves in a certain way since he experienced many positive and negative reinforcement, which shaped his attitude. Each behavior is conditioned, among other things, by reinforcements and attitudes towards the problem. Another representative of the behavioral school, referring simultaneously to the cognitive approach, was A. Bandura, creator of the theory of social learning. He believed that to understand human behavior, one can not base only on theories of learning, but should also take into account the interaction of social environment. People are shaped by the environment and actively create it. It is, next to the self, the source of reinforcements. Depending on their abilities, they learn by watching other people interact with the environment (Ziółkowska, 2008). The achievement of the behavioral school is widely used in psychological practice, including in solving social problems and different types of organizations, and it is a particular form of management of organizational behavior. Researchers of this trend showed that the use of behavioral procedures have a positive impact on employee behavior and eliminate those which are undesirable (Suchowierska, 2008). Behaviorism often allows keeping an effective therapy for behavioral pathologies (eg. the output of addiction such as work holism, behavior modification dangerous from the point of view of corporate organization) and is a method of exerting a beneficial effect in the educational process (and professional), and education. Training methods based on behavioral knowledge (eg. Job training, modeling behavior) mean that the employee can improve their professional competence, he becomes more restored to value for himself and his ability gives a certain sense. In addition, research conducted in this trend, especially in combination with concepts of cognitive, show how people value bonuses (including those received in the workplace), which leads them to desirable, from the point of view of influencing person, decisions and what shapes their different economic behavior (saving, risk-taking, insuring themselves). Behaviorism seeks to highlight the value of the human environment in which he works.

\section{Organizational culture}

A person, apart from being humanistic, behavioral creature, is also a cultural creature, which has its own cultural manners and is the giver, the co-author of organizational culture. The focus of this study is the organizational culture and therefore a person will be considered in the context of organizational culture.

In the literature you can meet a number of definitions of organizational culture (Stańczyk, 2008), where the concept of E. Schein sees organizational culture as a pattern of fundamental assumptions invented, discovered or developed by the group in learning process of how to deal with its problems of adaptation of the outer and inner integration (McKenna, Beech, 1999: 35). Shaping the organizational culture (Sułkowski, 2012) is based on the deliberate modification of values, norms and the resulting patterns, which should lead to new, coherent and more effective ones under certain conditions configurations of organizational culture (Sułkowski, 2001: 99-110). 
Among the techniques that can be used to shape the culture, including its fixation, correction, development, and changes one can name (Sułkowski, 2001: 101):

1) redefinition of organizational values,

2) creation of new normative rules,

3) changing the elements of culture (myths, stories, characters, patterns, symbols, rituals, taboos, language),

4) artifacts adaptation to the changing of the core,

5) the composition and the decomposition of the mission,

6) design of communication systems and power,

7) changing the job descriptions of work,

8) meetings, discussions, and training of employees,

9) shaping the roles of leaders in the organization (eg. as agents of change, role models, heroes, innovators),

10) development of incentive systems,

11) changing the selection criteria.

Organizational culture enables the improvement of the organization. It helps in creating conditions for the basics of management. As a result of consciousness possessed, every employee is aware that the effects of the work depend on the current state and potential businesses. The future management of the entity lies in the economic development of the organizational culture, which is the foundation of the identity of the organization. Certainly, it will lead to better management excellence and outstanding market results. Culture influences the success of the organization. Organizational culture is a guide to the accepted patterns of behavior, a determinant of norms and standards. It acts as an important factor in human resource management - can be a destructive force or supporting the development of knowledge in the organization. Management companies should focus on the development of such a culture that supports internal entrepreneurship, creative approaches to new problems, accepts defeat and stumbling during innovative solutions and promotes the exchange of information and internal communication. Company practice arose of organizational culture are the property of the company and the source of its competitive advantage. The effectiveness of organizational culture is dependent on the extent to which it is shared by the members of the organization. This is all the more difficult, the greater the change in the organizational culture and the more privileged groups losing position.

\section{Humanistic - behavioral - cultural competitive advantage of the enterprises - concept models}

The humanist concept, behaviorist concept together with organizational culture (personal culture is a part of the organizational culture) are the basis of human development and as a person at work (employee) which in turn helps to build competitiveness of the organization (company). It can be argued that the creator of the broad development, including the competitiveness of the organization, is the person. The person is the beginning and the end of the organization. Each person has his or her distinctive attributes, which can be generalized or refined. Considering the competitiveness of organizations in the context of the person, one can talk about behavioral - humanistic - cultural competitiveness, which you can qualify to detailed competitiveness. The following Figure 2 shows the three-level model of human organization - a conceptual model.

\section{I level}

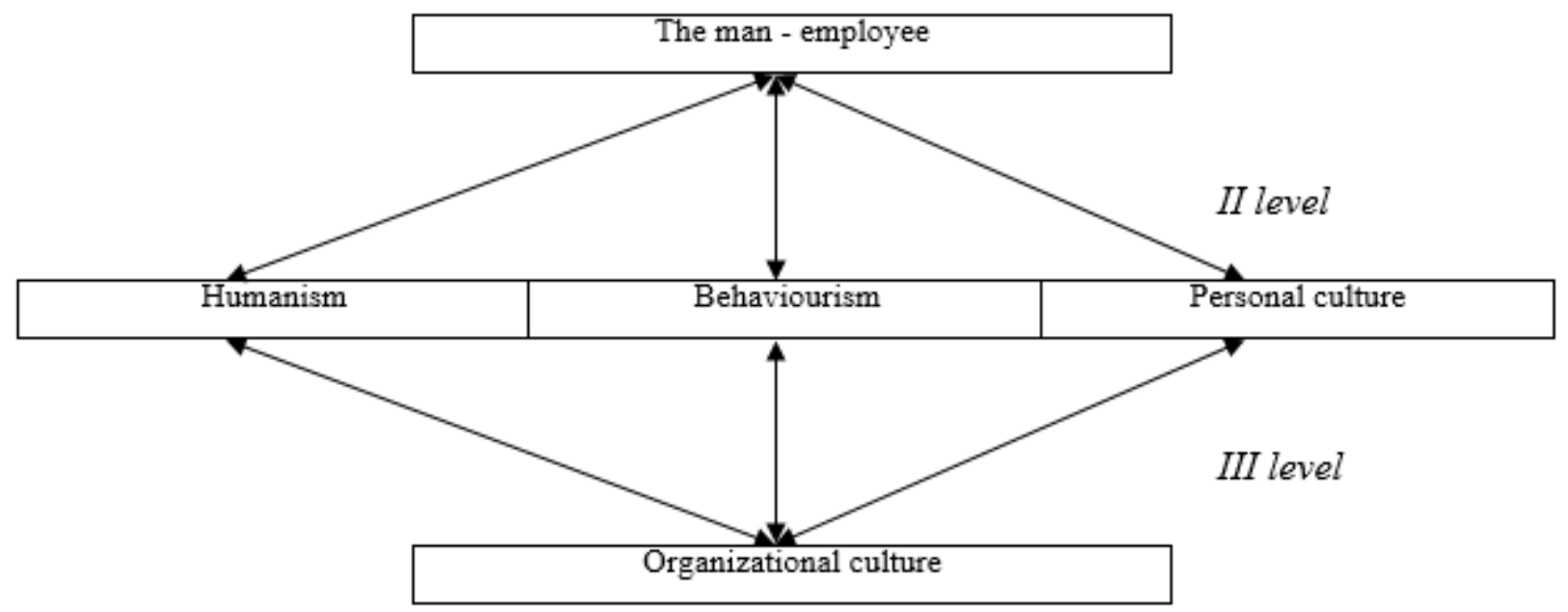

Source: Own authoring

Figure 2. The three-level model of human organization - a conceptual model 
ISSN (online) - 2520-6311; ISSN (print) - 2520-6761

The starting point of any organization is a person - a worker (level I), which is considered in terms of qualitative and not quantitative. The quality of human (employee) is the degree of his commitment and ability to offer a specific contribution to the development of the organization. A person is the first level from which any activities aimed at the development of the organization start. In determining the quality of a person, his attributes also help, which were included in a synthetic way (general) seen through the prism: humanism, behaviourism and personal culture (level II). These are the three attributes of being human in the organization. The first attribute is humanism understood as a person with his needs to be needed, respected, recognized and treated humanely. The second attribute is behaviourism understood as an interaction stimulus on human behavior. The third attribute is a personal culture understood as the acquisition of certain human norms, values, giving up socialization in the environment of human life. The person along with his attributes helps to create an organizational culture (level III), which shapes competitiveness, and ultimately contributes to the achievement of competitive advantage for organizations.

The three-level model of a person in the organization is perceived in a bi-directional way, i.e. a person by his attributes give rise to any action in the organization, to shape organizational culture and the shaped organizational culture affects the attributes of a person changing him as a person. It can be argued that in this model one can see a human socializing organization and the organization socializing a human.

The importance of human organization is so important that it contributes to the development of competitiveness and competitive advantage. From the point of view of process management (decision-making) in the organization, the supervisor (manager) should be considered, who through cooperation with subordinates manages competitiveness in order to achieve a competitive advantage. The manager makes decisions directly in the organization. The following Figure 3 shows a positive knowledge manager and a positive subordinate in shaping humanistic - behavioral - cultural competitive advantage of the enterprises - a concept model.

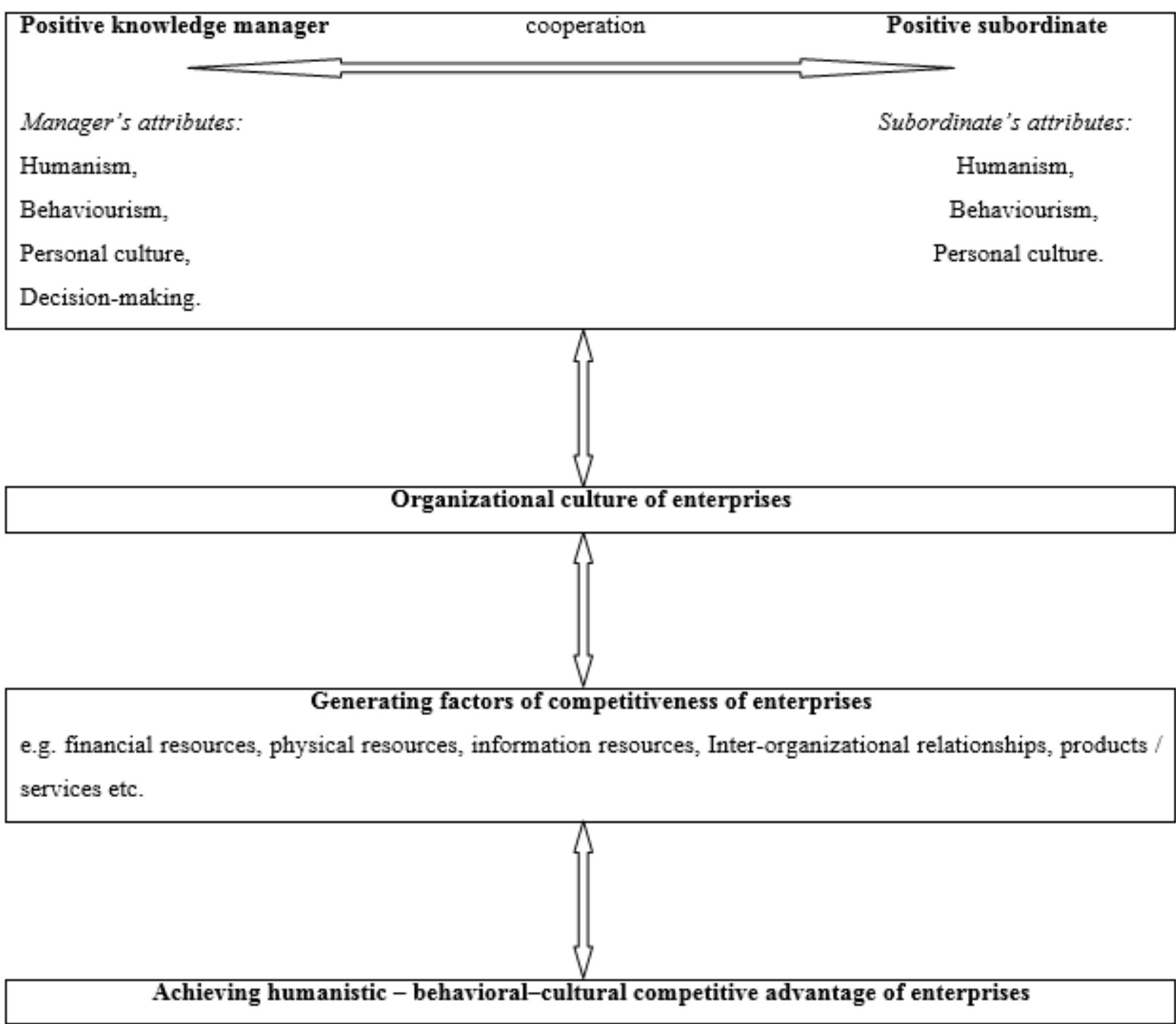

Figure 3. A positive knowledge manager and a positive subordinate in shaping humanistic - behavioral - cultural competitive Source: Own authoring advantage of the enterprises - a concept model 
The starting point in shaping humanistic - behavioral - cultural competitive advantage of enterprises is having one's own positive knowledge manager with positive subordinates. Both positive knowledge manager and positive subordinate derive from positive psychology, which is involved in the formation of human attributes. Between positive knowledge manager and positive subordinates logical, rational or fully understood cooperation must occur, as a result of which the organization will thrive. Another positive attribute of knowledge manager apart from humanism, behaviourism and personal culture is decision-making as a consequence of the implementation of the management process in the organization. The positive subordinate has the three attributes without the ability to make decisions because then he would not be a subordinate (employee executive). Attributes and cooperation of a positive knowledge manager and a positive subordinate contribute to shaping a favorable organizational culture for the entire organization, including competitive factors. Organizational culture generates competitiveness when it has a quality staff with a positive attitude who know how to look in a different way at everything that creates (internal environment) and surrounds the organization (external environment). The resources held by the organization are the benefit of a human, including the manager cooperating with subordinates. These resources such as financial resources, physical resources, information resources, etc. make up competitiveness. It can be argued that each type of organizational culture is good on the condition that it will contribute to creating competitiveness. Positive knowledge manager with positive subordinates in a conducive organizational culture to gain competitiveness create opportunities to achieve competitive advantage, which through human attributes is defined as humanistic - behavioral - cultural competitive advantage of enterprises.

The model of positive knowledge manager and positive subordinate in shaping humanistic - behavioral cultural competitive advantage of enterprises is shown in terms of a bi-directional, which means that it can be analyzed (direction: person $\longrightarrow$ competitive advantage) from positive knowledge manager and a positive subordinate through a corporate culture, competitive factors to the achievement of humanistic - behavioral cultural competitive advantage of enterprises and (direction: competitive advantage $\rightarrow$ person) from the achievement of humanistic - behavioral - cultural competitive advantage of enterprises through competitiveness, organizational culture and ending with a positive knowledge manager and a positive subordinate. The direction of the analysis depends on the situation in which the organization (enterprise) is. It can be argued that the person in the organization (employee) sets in motion what the organization creates to achieve competitive advantage and competitive advantage contributes to any change in the organization which means that internal environment mutually penetrates the external environment and the external environment penetrates the internal environment (mutual interpenetration of environments).

\section{Conclusion}

Undeniable resource of an organization (enterprise) in shaping the development, including competitiveness and competitive advantage, is the person - employee. It is he who gives the dynamics and direction of all activities and changes in the organization. In the person, one should seek quality rather than quantity. We can say that the quantity is a filler of people in the organization, and the quality is the core, substance, solid base for further existence. Proactive knowledge as a factor, pro-development, stimulating further constructive action must be a prominent factor in a manager. Knowledge manager with the subordinates are supposed to work together for the common good. Together they should have a positive attitude towards other people or have a positivity. Therefore, organizations should have positive knowledge managers and positive subordinates. With positivity and mutual cooperation, a lot can be achieved in many organizations. The involvement of human resource in the development of competitiveness and competitive advantage will be the sign of humanistic - behavioral - cultural competitive advantage of enterprises.

Theoretical research carried out in the form of interpretation of the available literature are presented in the form of conceptual models, representing the point of view of the author of this study. The interpretation of the available literature on the subject has led to achieving the objective pursued by the author, who can say that the purpose of development has been achieved in the form of a logical presentation of this report and two hypotheses adopted have been proven positively and eventually have taken the form of theses: Thesis 1: Humanism, Behaviourism, and Organizational culture are the attributes of a person enabling the achievement of competitive advantage; Thesis 2: Knowledge manager and subordinate let positivity guide shaping the competitive advantage of enterprises. The implicit argument is that every organization (enterprise) which wants to stay in business tends to have employees being people-minded, reactive, forming relationships with others, exhibiting a certain behavior, possessing manners written in the organizational culture, tending towards the achievement of competitive advantage by the enterprise. Every person wants good rather than evil, he 
Business Ethics and Leadership, Volume 3, Issue 1, 2019

ISSN (online) - 2520-6311; ISSN (print) - 2520-6761

wants to be positive rather than negative, so the positivity is the essence in the shaping of competitive advantage.

The author of this paper is convinced of the validity of the presented concept models, which can contribute to the improvement of the human resource management in organizations (enterprises) which want to creatively achieve a competitive advantage on the market.

\section{References}

1. Asllani, A., Luthans, F. (2003). What knowledge managers really do: an empirical and comparative analysis. Journal of Knowledge Management, 7(3), 53-66.

2. Cox, R. (2006). Posłowie. Bogaty plon Abrahama Maslowa [Members. Rich harvest of Abraham Maslow]. In: Motywacja i osobowość, ed. A. Maslow, 367-369, Warszawa: PWN.

3. Fredrickson, B. L. (2003). Positive Emotions and Upward Spirals in Organizations, In: Positive Organizational Scholarship, ed. K. S. Cameron, J. E. Dutton, R. E. Quinn, 163-175, San Francisco, Foundations of a New Discipline, Berrett-Koehler Publishers.

4. Glińska-Neweś, A. (2010). Pozytywny Potencjał Organizacji jako prorozwojowa architektura zasobów przedsiębiorstwa [Positive Organizational Potential as a development-oriented enterprise resource architecture]. In: Pozytywny Potencjał Organizacji. Wstęp do użytecznej teorii zarządzania, ed. M. J. Stankiewicz, 37-52, Toruń, Dom Organizatora.

5. Gulla, B., Tucholska, K. (2007). Psychologia pozytywna: Cele naukowo-badawcze i aplikacyjne oraz sposób ich realizacji [Positive psychology: Scientific and research objectives and the way of their implementation]. In: Studia z psychologii, ed. P. Francuz, W. Otrębski, 133-152, Lublin: KUL.

6. Hall, C.S., Lindzey, G. (2001). Teorie osobowości [Theories of personality]. Warszawa: PWN.

7. Haffer, R. (2010). Relacje pomiędzy komponentami modelu wewnątrzorganizacyjnych oddziaływań Pozytywnego Potencjału Organizacji [Relations between the components of the model of intraorganizational interactions of the Positive Organization Potential]. In: Pozytywny Potencjał Organizacji. Wstęp do użytecznej teorii zarządzania, ed. M. J. Stankiewicz, 159-213, Toruń: Dom Organizatora.

8. Krogh, G. (1998). Care in Knowledge creation. California Management Review, 40(3), 133-153.

9. Leśniewski, M. A. (2014). Konkurencyjność zasobowa przedsiębiorstw [Resource competitiveness of enterprises]. Ekonomika i Organizacja Przedsiębiorstwa, 4(771), 57-68.

10.Leśniewski, M. A. (2015). Wiedza w strategiach zarządzania przedsiębiorstwem. Zarządzanie wiedzą. Studium teoretyczne [Knowledge in business management strategies. Management of knowledge. Theoretical study]. In: Ekonomia, zarządzanie i rozwój regionalny. Pomiędzy światem polityki a życiem naukowym. Księga jubileuszowa dedykowana Profesorowi Wojciechowi Saletrze, ed. J. Jaskiernia, R. Kubicki, tom III, 171-187, Kielce: Uniwersytet JanaKochanowskiego.

11.Leśniewski, M. A. (2017). Behavioural-humanistic model of soft competitiveness of enterprises. Jagiellonian Journal of Management, 3(2), 77-91.

12.Leśniewski, M. A. (2018). Pozytywny menedżer wiedzy decydentem stymulowania rozwoju zasobów przedsiębiorstwa [Positive knowledge manager as the decision maker to stimulate the development of enterprise resources]. Akademia Zarzadzania, 2(1), 79-98.

13.Leśniewski, M. A. (2018a). Człowiek Konkurencyjności - model koncepcyjny [Competitive Man - $a$ conceptual model]. In: Kierunki ewolucji nauk o zarządzaniu, ed. M. Budzanowska-Drzewiecka i K. Czernek., 123-135, Kraków: Uniwersytet Jagielloński.

14.Maslow, A.H. (2006). Motywacja i osobowość [Motivation and personality]. Warszawa: PWN.

15.Matusewicz, C. (2006). Wprowadzenie do psychologii [Introduction to psychology]. Warszawa: Wizja Press \& IT.

16.McKenna, E., Beech, N. (1999). Zarządzanie zasobami ludzkimi [Human resource management]. Warszawa: Felberg SJA.

17.McKeen, J. D., Staples, D.S. (2003). Knowledge managers: Who they are and what they do. In: Handbook on knowledge management band 1, ed. C. W. Holsapple, Berlin: Springer Verlag.

18.Perechuda, K. (2005). Pracownicy wiedzy jako kreatorzy sieciowych potencjałów [Knowledge workers as creators of network potentials]. Zarzadzanie Zasobami Ludzkimi, 5, 9-15.

19.Roberts, L. M. (2007). From Proving to Becoming: How Positive Relationships Create a Context for SelfDiscovery and Self-Actualization. In: Exploring Positive Relationships At Work: Building a Theoretical and Research Foundation, ed. J. E. Dutton, B. R. Ragins, 23-31, Mahwah: Laurence Erlbaum Associates.

20.Rogers, C. (1991). Terapia nastawiona na klienta. Grupy spotkaniowe [Therapy focused on the client. Meeting groups]. Wrocław: Thesaurus-Press. 
21.Romańczuk, A. (2003). Praktyka zarządzania wiedzą w przedsiębiorstwie [Knowledge management practice in an enterprise]. In: Zarządzanie wiedzą w przedsiębiorstwie, ed. B. Wawrzyniak, Warszawa: Wyższa SzkołaPrzedsiębiorczości i Zarządzania im. L. Koźmińskiego.

22.Stańczyk, S. (2008). Nurt kulturowy w zarządzaniu [Cultural trend in management]. Wrocław: Uniwersytet Ekonomiczny.

23.Stachowski, R. (2000). Historia psychologii: Od Wundta do czasów najnowszych [History of psychology: From Wundt to the newest times]. In: Psychologia (vol. 1), ed. J. Strelau, 40-45, Gdańsk: Gdańskie Wydawnictwo Psychologiczne.

24.Suchowierska, M. (2008). Stosowana analiza zachowań - wykorzystanie technik behawioralnych do rozwiązywania problemów społecznych [Applied behavior analysis - using behavioral techniques to solve social problems]. In: Współczesnapsychologia behawioralna, ed. P. Bąbel, P. Ostaszewski, 239-260, Kraków: Uniwersytet Jagielloński.

25.Sułkowski, Ł. (2001). Czy jest możliwe kształtowanie kultury organizacyjnej? [Is it possible to shape the organizational culture?]. Organizacja i Kierowanie, 4, 99-110.

26.Sułkowski, Ł. (2012). Kulturowe procesy zarządzania [Cultural management processes]. Warszawa: Difin.

27.Trojan, M. (2014). 100-lecie manifestu behawiorystycznego Johna Watsona [The 100th anniversary of John Watson's behaviorist manifesto]. Retrieved from: maciejtrojan. natemat.pl [accessed: 19.06.2018].

28.Tyszka, T., Zaleśkiewicz, T. (2004). Psychologia pieniądza [Psychology of money]. In: Psychologia ekonomiczna, ed. T. Tyszka, 174-176, Gdańsk: Gdańskie Wydawnictwo Psychologiczne.

29.Zbierowski, P. (2012). Orientacja pozytywna organizacji wysokiej efektywności [Positive orientation of the high efficiency organization]. Warszawa: Oficyna Wolters Kluwer Business.

30.Ziółkowska, A. M. (2008). Osobowość w ujęciu psychologii behawioralnej [Personality in terms of behavioral psychology]. In: Współczesna psychologia behawioralna, ed. P. Bąbel, P. Ostaszewski, 154157, Kraków: Uniwersytet Jagielloński. 